Bangladesh J. Bot. 43(3): 243-247, 2014 (December)

\title{
MORPHOLOGY, ANATOMY AND PALYNOLOGY OF ENDEMIC CYCLAMEN MIRABILE HILDEBR. (PRIMULACEAE) IN SOUTH-WEST TURKEY
}

\author{
Olcay Dinc Dusen*, Betul Gurcan and Ramazan Mammadov \\ Department of Biology, Faculty of Science and Arts, Pamukkale University, Denizli, 20017,Turkey
}

Key words: Cyclamen mirabile, Endemic, Anatomy, Morphology, Palynology

\begin{abstract}
Morphological, anatomical and palynological properties of Cyclamen mirabile Hildebr. endemic to Anatolia, Turkey have been determined. Typifications, synonym lists, descriptions, ecology and phytogeography are provided for the species and its relationships to similiar species are discussed. The anatomical study from different plant parts of $C$. mirabile have been made for the first time. Its pollen morphologies were also defined. Morphological findings obtained in the present investigation were generally consistent with those given in the Flora of Turkey with some exceptions in numerical data.
\end{abstract}

\section{Introduction}

The genus Cyclamen L. was formerly classified under the family Myrsinaceae (Källersjö et al. 2000), but recently it has been re-classified under the family Primulaceae. Cyclamen is a genus of c. 21 species of tuberous perennials with bright, colourful flowers that are widely grown in gardens, and as house plants (Yesson et al. 2009). Cyclamen is primarily distributed around the Mediterranean, but it extends eastwards as far as the shore of the Caspian sea. There is also a single isolated species (C. somalense Thulin \& Warfa) to be found in a small patch of Somalia (Yesson and Culham 2006). The species of the genus share several characteristic features that diagnose them as a monophyletic group, e.g. a well-developed tuberous subterranean bulb formed by swelling of the hypocotyl, conspicuously reflexed corolla lobes and coiled fruiting pedicels (Anderberg et al. 2000). Cyclamen tubers have toxic saponins in large amounts. Although the tubers have posinous saponin, wild boars look for them and eat without any post effect (Zeybek and Zeybek 1994). Nicotiana (tobacco) breeders use its tubers (as diluted infusion) to protect their goods against below ground predators in their young seedlings (Baytop 1999).

The genus Cyclamen is commonly known as "slklamen, domuzturpu, topalak, yersomunu" in south-west Anatolia. The genus Cyclamen is represented by 12 species in Turkey and six of them are endemic to Anatolia (Meikle 1978, Ekim 2000). C. mirabile is one of the six endemic species of the genus from Turkey. It grows naturally in the south-western part of Turkey, especially in Muğla, Aydın and Isparta (Meikle 1978).

In litarature, there are no detailed morphological, anatomical and palynological studies on $C$. mirabile, nor on other Cyclamen species in Turkey. In this research, detailed morphological, anatomical and palynological properties of $C$. mirabile have been determined.

\section{Materials and Methods}

The samples of Cyclamen were collected from Akçaova (Muğla) in 2008 and later on prepared standard herbarium for morphological study and preserved in the Pamukkale University herbarium (PAMUH) (Fig. 1a). The Flora of Turkey (Meikle 1978) was used for the identification and

*Author for correspondence: <odusen@pamukkale.edu.tr>. 
description of C. mirabile. Some of the dried and fresh plant samples were used for morphological measurements and their detailed descriptions were prepared. The conservation status of the species was evaluated according to IUCN threat categories (Ekim et al. 2000, IUCN 2001). Typifications, synonym lists, descriptions, ecology and phytogeography are provided for C. mirabile and relationships to similiar species are discussed. The plant samples were fixed in $70 \%$ ethanol for anatomical investigations. In anatomical analysis, transverse sections of root and leaves were prepared. Anatomical descriptions for the species were prepared, supported by light microscopic photographs with an Olympus CX31.

The palynological part of this study was made using Light Microscope (LM) and Scanning Electron Microscope (SEM) on pollens of C. mirabile. The pollen samples were obtained mostly from freshly collected herbarium specimens. For LM studies pollen grains were mounted directly with basic-Fuchsine-glycerin jelly (Wodehouse 1935). For SEM investigation, the pollen grains were transferred directly to double-sided tape affixed stubs and were sputter-coated with gold plates. Photomicrographs were taken with a Zeiss-Leo 14320 Electron Microscope at the University of Akdeniz, Faculty of Medicine, Deparment of Histology and Embryology.

\section{Results and Discussion}

Perennial herbs with tuberous rootstocks. Tuber usually $3-6 \mathrm{~cm}$ in diam, with a corky, lightly fissured surface. Leaves appearing with flowers in autumn, suborbicular, $1-3(3.5) \mathrm{cm}$ long and about the same as wide, lamina commonly somewhat toothed and often with pink or reddish marbling above, especially when young, long petiole generally arising directly from tuber, glabrous. Flowers solitary, axillary and nodding, appearing in autumn. Pedicel long, usually coiling spirally in fruit. Calyx deeply 5 lobed. Corolla pale pink with darker basal blotches, lobes $1.5-2 \mathrm{~cm}$ long, not auriculate, toothed or shortly erose-laciniate at apex, rather densely glandularpapillose internally (reflexed externally). Stamens 5, inserted at base of corolla. Ovary superior; style slender, usually shortly exceeding anthers. Fruit a broad capsule, splitting from apex into 5 curved teeth; many seeded, seeds spongy, coated with a sticky secretion.

This species is endemic and is distributed in the south-west Anatolia. It flowers during September to November and prefers organic rich soils that are formed from rocky and stony slopes in Quercus macchie and Pinus brutia woodland at $500-1000 \mathrm{~m}$ attitude.

C. mirabile is "endangered (EN)" according to Red Data Book of Turkish Plants (Ekim et al. 2000) and revised IUCN (2001). Our assessments agree with these two evaluations. Due to anthropogenic effects such as grazing, tourism, industrialization and urbanization, the decrease in population of the species was observed. Consequently, the species faces immediate threat.

C. mirabile is related to C. cilicicum Boiss. \& Heldr (Table 1).

A transverse section taken from the middle part of the root is observed as follows (Fig. 2). The root is covered by a thick cuticular layer on upper surfaces. There are many eglandular hairs on the cuticule. The epidermis is composed of a single layer of cells, the cells are 4 sided, and 23.77 $46.15(35.19) \mu \mathrm{m} \times 30.76-58.97$ (43.58) $\mu \mathrm{m}$ in size. There is usually a single-layered exodermal tissue below the epidermis. Cortex is $12-15(-20)$ layered and consists of parenchyma. The cortex tissue consists of large hexagonal, semi-circular or oval parenchymatous cells, measuring $12.82-64.10$ (37.64) $\mu \mathrm{m} \times-23.07-79.48(47.43) \mu \mathrm{m}$. The single-layered endodermis consists of 3 thick-walled cells. Xylem is composed of sclerenchymatic cells and trachea. In the pith a primary xylem tissue is present. Secondary xylem has hard sclerenchymatic cells and trachea. 

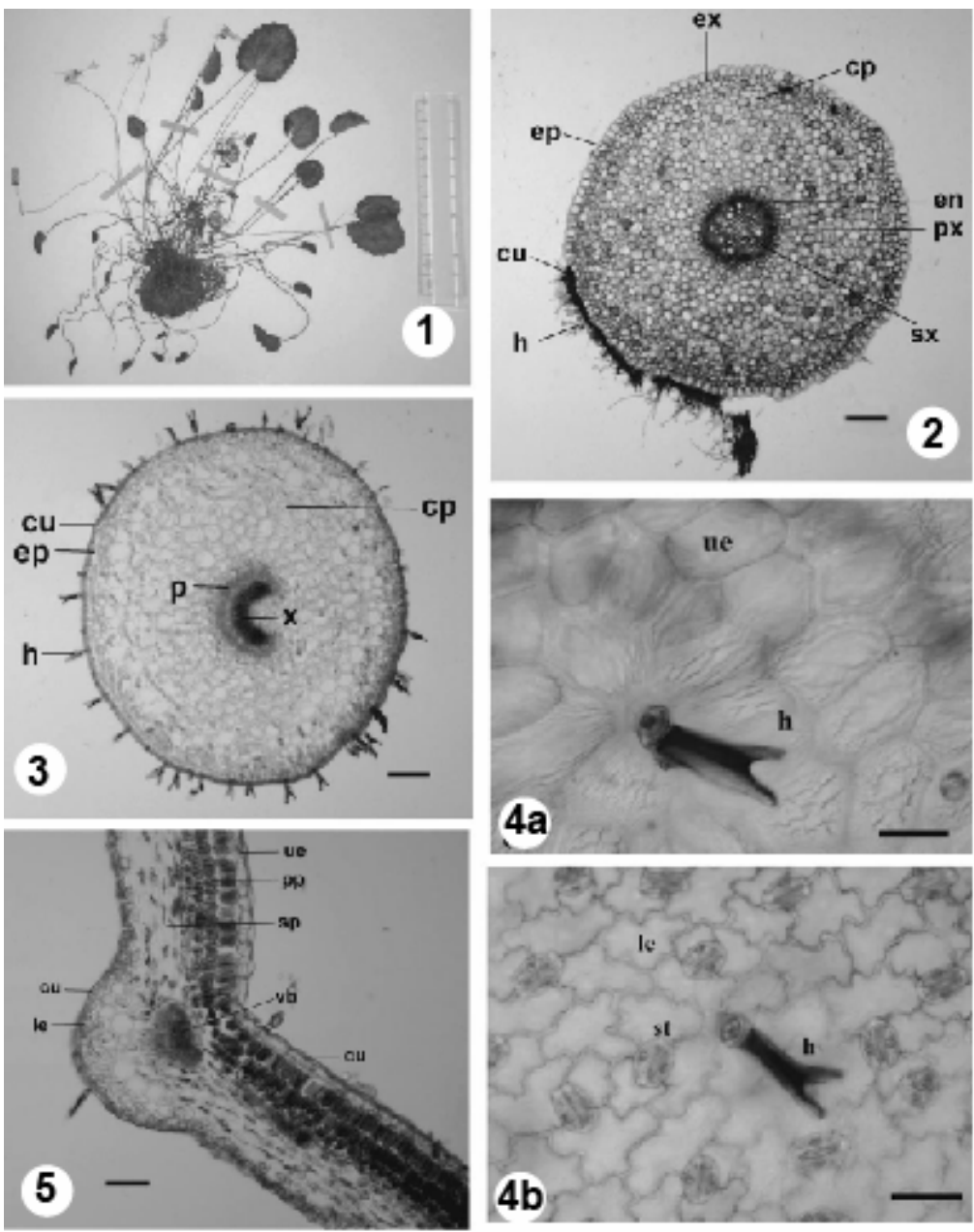

$4 a$
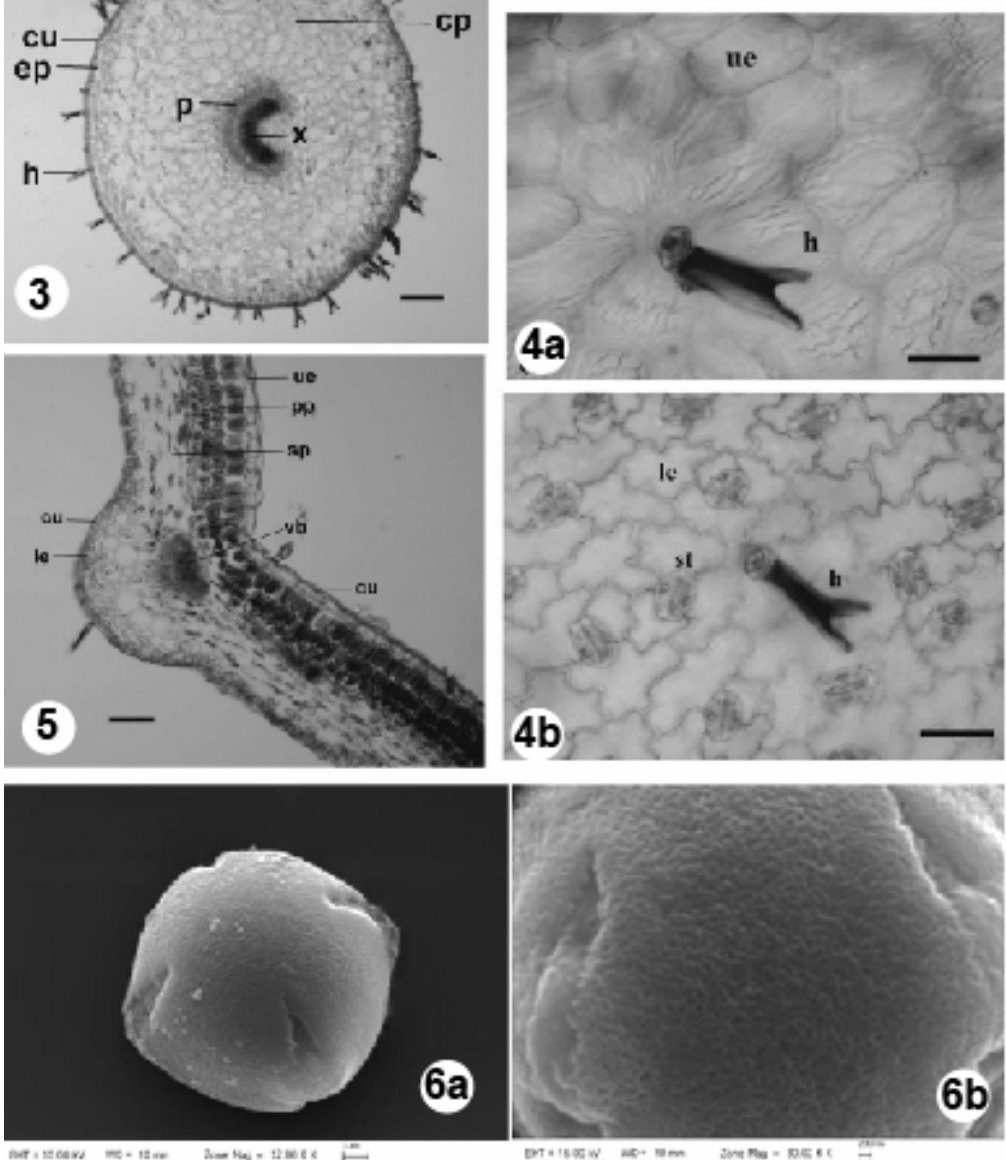

Figs 1 - 6. 1. General appearance of Cyclamen mirabile. 2 - 5. Anatomical and morphological features of different plant parts of C. mirabile. 2. Cross section (cs) of the root (bar $175 \mu \mathrm{m})$; 3. cs of petiole (bar $=$ $350 \mu \mathrm{m})$, 4. Anatomy of leaf. a. upper, b. lower $(\mathrm{bar}=18.5 \mu \mathrm{m}), 5$. CS of lamina midrib $(\mathrm{bar}=85 \mu \mathrm{m}), 6$. Palynological features of $C$. mirabile. a. pollar view $(\mathrm{bar}=1 \mu \mathrm{m})$, b. exine sculpturing $(\mathrm{bar}=200 \mu \mathrm{m})$. $\mathrm{h}$ : hair, cu: cuticle, ep: epidermis, ex: exodermis, cp: cortex parenchyma, en: endodermis, px: primary xylem, sx: secondary xylem. p: phloem, x: xylem, le: lower epidermis, st: stomata, ue: upper epidermis, pp: palisade parenchyma, sp: spongy parenchyma, vb: vascular bundle, cu: cuticle. 
A transverse section taken from the middle part of the petiole is observed as follows (Fig. 3). The petiole is covered by a thin cuticular layer on upper surfaces. There are many hairs on the cuticula. The epidermis is single-layered, with thin walled oval or angular cells. Cortex is many layered and consists of parenchyma. The cortex tissue consists of large hexagonal, oval or orbicular parenchymatous cells without intercellular spaces. Vascular bundle is only one and located in the centre of petiole. The vascular bundles vary in size.

Table 1. Comparison of morphological characteristics between $C$. mirabile and $C$. cilicicum.

\begin{tabular}{lll}
\hline $\begin{array}{l}\text { Morphological } \\
\text { characters }\end{array}$ & \multicolumn{1}{c}{ C. mirabile } & \multicolumn{1}{c}{ C. cilicicum } \\
\hline Leaves & $\begin{array}{l}\text { Often distinctly toothed, commonly with } \\
\text { reddish marbling above especially when } \\
\text { young }\end{array}$ & $\begin{array}{l}\text { Entire or inconspicuously toothed, } \\
\text { unmarbled or with pale grey marbling }\end{array}$ \\
Petiole & $\begin{array}{l}\text { Generally arising directly from tuber and } \\
\text { not geniculate at base }\end{array}$ & $\begin{array}{l}\text { Geniculate at base } \\
\text { Corolla lobes }\end{array}$ \\
$\begin{array}{l}\text { Pale pink with darker basal blotches, 18-20 } \\
\text { mm long, toothed or shortly erose-laciniate } \\
\text { at apex, rather densely glandular }\end{array}$ & $\begin{array}{l}\text { Whitish or pale pink with or without } \\
\text { crimson basal blotches, 10-18 mm } \\
\text { long, entire or subentire, eglandular or } \\
\text { very sparsely glandular within }\end{array}$ \\
\hline
\end{tabular}

Lamina surface preparations of both epidermises (Fig. 4) and the transverse section of the lamina-midrib (Fig. 5) revealed the following elements. Leaves are covered by a thick cuticular layer on both upper and lower surfaces. There are many eglandular hairs on both epidermal surfaces. The upper and lower epidermises comprise uniseriate, large, oval and angular cells. The cells of the upper epidermis are larger than those of the lower epidermis. Upper epidermal cell measures 23.07 - $51.28(35.42) \mu \mathrm{m} \times 38.46-97.43(58.27) \mu \mathrm{m}$ in size, lower epidermal cell measures 15.38 - $38.46(25.05) \mu \mathrm{m} \times 17.94-51.28(34.73) \mu \mathrm{m}$ in size.

Leaf is bifacial. Mesophyll cells are more or less uniform in shape. Vascular bundles lie between the palisade and the spongy tissue and are surrounded by prenchymatous bundle sheathings. The type of vascular bundle is collateral. Palisade parenchyma cells are usually 3-5 layered, rich in chloroplast, and $17.94-51.28(30.06) \mu \mathrm{m} \times 43.58-64.10(53.02) \mu \mathrm{m}$ in size. Spongy parenchyma cells are $5-7$ - layered, poor in chloroplast, and $28.20-51.28(35.68) \mu \mathrm{m} \times$ $41.02-79.48(59.82) \mu \mathrm{m}$ in size. Stomata is anisocytic type and located on the lower epidermal surface.

Pollen grains are monads, tetracolporate, spheroidal (Fig. 6a). Polar axis (P) is $13.86 \pm 1.30$ $\mu \mathrm{m}(12.82-16.66 \mu \mathrm{m})$, equatorial axis (E) $13.16 \pm 0.78 \mu \mathrm{m}(12.82-15.38 \mu \mathrm{m})$. P/E ratio is 1.05 $\mu \mathrm{m}$. Exine $2.564 \mu \mathrm{m}$ thick, tectate. The exine sculpture is reticulate (Fig. 6b).

In this study, morphological, anatomical and palynological properties of Cyclamen mirabile Hildebr. have been investigated. The results obtained from the morphological studies were compared with the description of this species in the "Flora of Turkey" (Meikle 1978). Our morphological findings of C. mirabile were generally consistent with these given in the Flora of Turkey (Meikle 1978) with some exceptions in the numerical data. In the light of this study, the description of species is enlarged and contributed to the Flora of Turkey. The anatomical investigations of C. mirabile are reported for the first time in this study. The transverse sections of the root, leaf and petiole, and the leaf surface anatomy were investigated. In addition, the pollen grains of C. mirabile were investigated by using SEM (Scanning electron microscope). The scanning electron micrographs of the pollen grains of $C$. mirabile are reported for the first time in Turkey. 


\section{References}

Anderberg AA, Trift I and Källersjö M 2000. Phylogeny of Cyclamen L. (Primulaceae): Evidence from morphology and sequence data from the internal transcribed spacers of nuclear ribosomal DNA. Plant Systemat. Evol. 220: 147-160.

Baytop T 1999. Türkiye'de Bitkiler ile Tedavi, Geçmişte ve Bugün. Nobel Tıp Kitabevleri Ltd. Şti., İstanbul. pp. 480.

Ekim T 2000. Cyclamen L. In: Flora of Turkey and the East Aegean Islands, Güner A, Özhatay N, Ekim T and Başer KHC (Eds), Vol. 11, pp. 184. Edinburgh Univ. Press, Edinburgh.

Ekim T, Koyuncu M, Vural M, Duman H, Aytaç Z and Adıgüzel N 2000. Red Data of Turkish Plants. The Council of Protecting the Turkish Nature Press 18, Ankara. pp. 96.

IUCN 2001. IUCN Red List Categories: Version 3.1. IUCN Species Survival Commission. IUCN, Gland, Switzerland and Cambridge, UK.

Källersjö M, Gerquist Gand Anderberg AA 2000. Generic Realigment in Primuloid Families of the Ericales s.l.: A Phylogenetic Analysis Based on DNA sequences from three chloroplast genes and morphology. Am. J. Bot. 87(9): 1325-1341.

Meikle RD 1978. Cyclamen L. In: Flora of Turkey and the East Aegean Islands, Davis PH (Ed), Vol. 6, pp. 128-135. Edinburgh Univ. Press, Edinburgh.

Yesson C and Culham C 2006. A phytoclimatic study of Cyclamen. BMC Evolutionary Biology 6: 72 (23 $\mathrm{pp})$.

Yesson C, Toomey NH and Culham A 2009. Cyclamen: time, sea and speciation biogeography using a temporally calibrated phylogeny. J. Biogeogr. 36:1234-1252.

Wodehouse RP 1935. Pollen Grains, Mc Graw Press, New York, pp. 106-109.

Zeybek N and Zeybek U 1994. Farmasötik Botanik, Ege Üniv. Ecz. Fak. Yay. No. 2, Bornova-İzmir.

(Manuscript received on 8 November, 2012; revised on 15 July, 2014) 